\title{
Г.І. Рибак
}

Харківський національний університет міського господарства імені О.М. Бекетова, Украӥна

\section{ОСВІТНІЙ ПОТЕНЦІАЛ ЯК ОСНОВА ІННОВАЦІЙНОГО РОЗВИТКУ УКРАЇНИ: МІЖНАРОДНЕ ПОРІВНЯННЯ}

Стаття присвячена аналізу впливу освіти на створення інноваційного потенщіалу крайни як інституційної складової. Розглянуто освітній потенціал як складову індексу інклюзивного розвитку краӥни та його вплив на розвиток економіки та виникнення інновацій у міжнародному розрізі. Проведено порівняльний аналіз капіталізації освітнього потенціалу. Підкреслено перспективні напрямки розвитку людського капіталу Украӥни та очікувані ефекти для розвитку краӥни від залучення інтелектуального капіталу.

Ключові слова: інноваційний розвиток, освітній капітал, освітній потенціал, інклюзивний розвиток, інституцііоналізація інноваційного розвитку, капіталізація освітнього капіталу.

\section{Постановка проблеми}

Освітній капітал стає одним з головних факторів розвитку економік країн світу та суспільства. Інвестиції в людський капітал стимулюють темпи економічного зростання, що $\epsilon$ передумовою конкурентоздатності країни на світовій арені. Якість людського капіталу в більшій мірі формується системою освіти.

Становлення незалежної Української держави, iii поступальний економічний розвиток, побудова стратегії модернізації економіки і перехід країни до інноваційного розвитку неможливий без освітнього потенціалу. У світовому просторі, за визначенням ЮНЕСКО, у XXI ст. освітній потенціал має стати панівною складовою інноваційного розвитку.

\section{Аналіз останніх досліджень і публікацій}

Проблеми розвитку освіти хвилюють багатьох фахівців. 3-поміж них варто відзначити таких іноземних науковців, як: Й. Шумпетер, М. Портер, та вітчизняних науковців В. Андрущенка, Д. Козенкова, В. Кременя, Е Ковальчука, В. Лугового, С. Максименко, О. Мельничука, О. Пищуліну, П. Сауха, И. Янковську[1-6, 8, 9] та інших. Але питання й досі залишається не в повній мірі розкритим, тому й досі потребує дослідження, пошуку та узагальнення основних напрямів інноваційного розвитку освітньої сфери.

Метою даної статті є аналіз особливостей та суперечностей розвитку освітнього капіталу та обгрунтування його впливу на інноваційні процеси в Україні 3 урахуванням закордонного досвіду i конкурентних переваг.

\section{Виклад основного матеріалу}

Для української економіки з характерними для неї недосконалими інститутами цей елемент людського капіталу має принципове значення, оскільки саме в ньому знаходяться резерви для інституційного оновлення не тільки ділового середовища, а й соціальних інститутів. В останні роки ключовим елементом людського капіталу країни став інтелектуальний капітал - здатність генерувати i освоювати інновації, свого роду економічна проекція творчої діяльності. Інтелектуальний капітал $\epsilon$ вирішальним для модернізації економіки, переходу до нових технологічних укладів [4, с. 23]. Сьогодні це такий же цінний ресурс, як і енергоносії, земля, капітал. В умовах постійних трансформаційних процесів проблема пошуку шляхів інноваційного розвитку освітнього потенціалу залишається актуальною i сьогодні.

Найважливішими характеристиками освітнього потенціалу є охоплення населення різними видами i формами загальної та професійної освіти, його якісні параметри, стан інфраструктури, фінансова складова, розвиток після вузівської освіти, рівень культури населення і його світоглядна орієнтація, духовний розвиток, можливість систематично отримувати i використовувати необхідну інформацію [3, с. 53]. Ці чинники впливають на ступінь включеності українського суспільства в національні і світові загальнолюдські процеси прогресивного розвитку. Освіта, що відповідає сучасним потребам суспільства i ринку праці, виступає могутнім адаптивним потенціалом у швидкоплинному суспільстві, що трансформується до сучасних соціально- 
економічних реалій, що стає найважливішою умовою успішного і стійкого суспільного розвитку.

Стан освітнього потенціалу розглядається в якості складової частини при розрахунку індексу інклюзивного розвитку країн. Інклюзивне зростання - це концепція, яка забезпечує справедливі можливості та рівноправ'я для економічних учасників, що супроводжується вигодами, принесеними кожному сектору економіки та різним верствам суспільства. Даний підхід розширює традиційні моделі економічного зростання та включає зосередження уваги на рівності здоров'я, людського капіталу, екологічного стану довкілля, соціального захисту та продовольчої безпеки як чинників світової безпеки в широкому розумінні [1, c. 104].

У розвинених країнах світу досягнення інклюзивного розвитку розглядається за умов першочергового розвитку освітньої інфраструктури у контексті інноваційного розвитку, що залучена до активної інноваційної політики як цілеспрямована система заходів інноваційного характеру (рис.1).

\section{"Розумне" зростання}

-розвиток економіки на основі знань та інновацій

\section{Сталий розвиток}

-сприяння більш ресурсозберігаючому, екологічно чистому виробництву -більш конкурентоспроможна економіка

\section{Інклюзивний розвиток}

-сприяння високому показнику зайнятості, що забезпечує економічну, соціальну й територіальну єдність

Рис. 1. Місце інклюзивного розвитку в системі основних пріоритетів для Європи згідно зі Стратегією розвитку до 2020 року [10, с. 11]

Це в поєднанні 3 виховною функцією освіти вносить в суспільний розвиток необхідну стійкість, перетворює економічне зростання в основу підвищення якості життя всіх верств населення.

Сьогодні за рівнем освіченості населення Україна випереджає країни 3 таким же рівнем грошових доходів. Україна входить до країн, які мають високий рівень населення 3 вищою та середньою професійною освітою. За даними Організації Об'єднаних Націй $(\mathrm{OOH})$, освітній потенціал, як складова індексу людського розвитку в Україні оцінюється порівняно високо, і саме тому, незважаючи на низьку тривалість і відносно низький рівень життя населення, Україна в цілому займає за даними на 2018 р 88-е місце в рейтингу країн за ІРЛП [12]. За даними Світового банку в межах дослідження Human Capital Index людський капітал України оцінено як такий, що вище середньосвітового рівня (50-те місце серед 157) [13].

В останні роки економіка України орієнтована на інноваційний розвиток, бо без залучення інновацій неможливий розвиток економіки, як стверджував у своїх наукових дослідженнях Портер [8, с.267]. Саме інститути науки та освіти ( інститути академічної науки, вищі навчальні заклади, науководослідні центри, виробничо-експериментальні організації, та ін.) здатні забезпечити такий розвиток, а також впровадження науки у практику (рис.2).

Відповідно до схеми, без інновацій в освіті та науці не можливі загальні інновації в країні, бо вони
$€$ їх основою. Особливу увагу необхідно приділяти вдосконаленню вищої та середньої професійної освіти. Великої уваги цим аспектам надають у США, де освіта $є$ доволі мобільною, швидко реагує на будьякі зміни в житті суспільства та потреби часу, де вкладення в людський капітал дуже значні. Слід зазначити, що і Україна витрачає значну суму своїх бюджетних ресурсів на освіту. Ї̈̈ норму закріплено в Законі України «Про освіту» у розмірі 7\% ВВП. За даними Світового банку, з 2013 до 2017 року бюджетне фінансування освіти в Україні зменшилося $37,2 \%$ до $6 \%$ ВВП [7, с.12]. Після стрімкого знецінення гривні, державні видатки на освіту в реальному вираженні ще зменшилися на $35 \%$ протягом двох років, що відображає не пріоритетність освіти для уряду, а також намагання стимулювати вищі навчальні заклади заробляти ще більше грошей у процесі роботи, і відповідно прилаштовуватися до нових інноваційних тенденцій розвитку освітньої сфери. Не зважаючи на те, що даний показник України знизився, він залишається на рівні показників інших країн (Німеччина $-4,4 \%$ ВВП, Японія - 3,4 \% , Іспанія - 4,4 \% , Італія - 4,3\% , США - 5,5 \% , Франція і Велика Британія - 5,6\%) i можна констатувати, що державне фінансування освітньої діяльності в Україні перебуває, за відносними показниками, на рівні найбільш розвинених країн світу, а то й перевищує його [7, с.8]. 


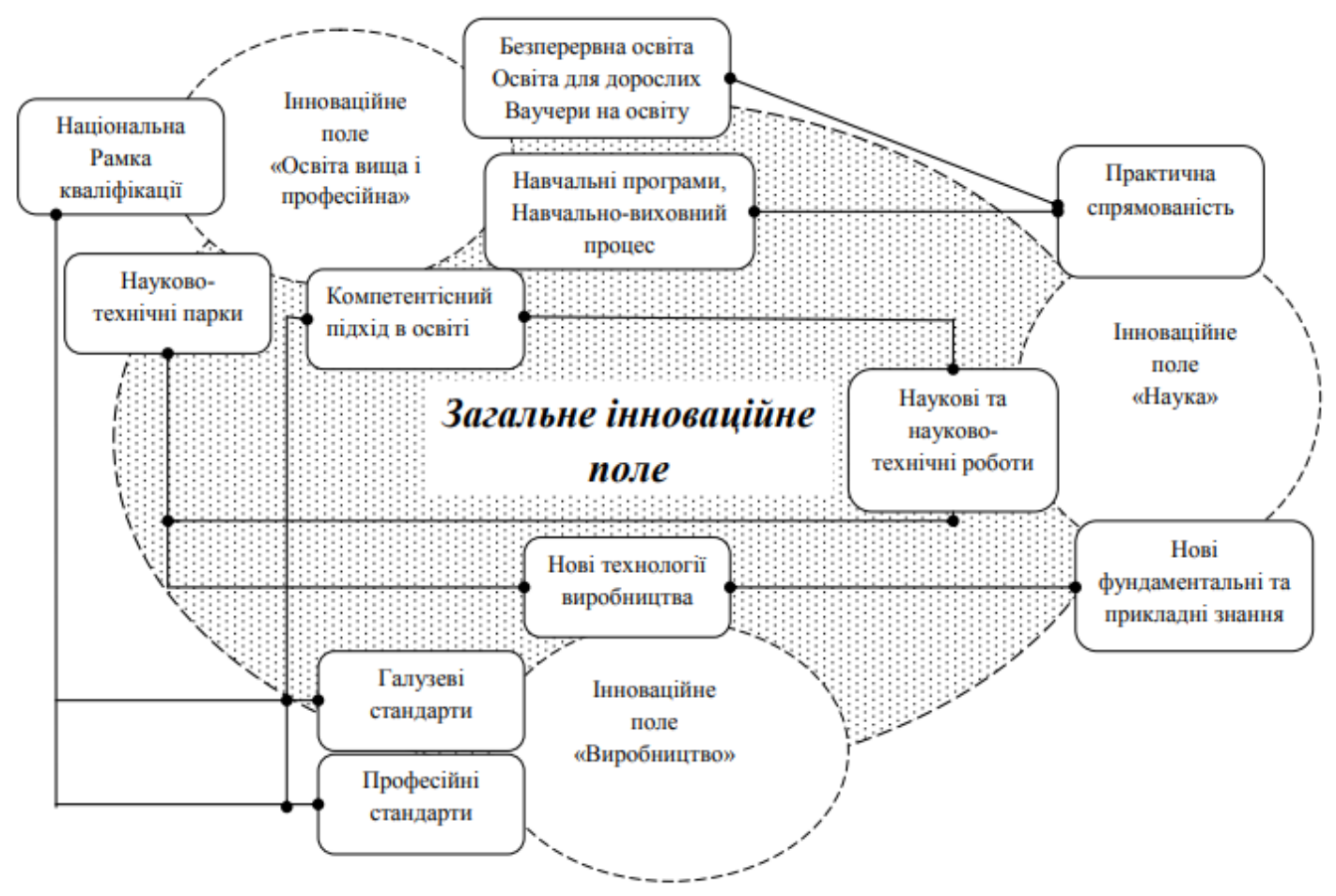

Рис. 2. Схема засад загального інноваційного поля [5, с. 168].

Але слід мати на увазі, що цей валовий показник не відображає якісних аспектів здобуття знань. I в абсолютному вимірі становище не таке втішне через значно менший, порівняно з розвинутими країнами, обсяг ВВП України. Окрім того високий формальний освітній потенціал українського населення не капіталізується в повній мірі: в групі країн з високим охопленням населення вищою i середньою професійною освітою в Україні самий низький ВВП на душу населення та недостатня динаміка продуктивності праці (рисунок 3). Рисунок 3 відображає пряму залежність вкладень у освіту i продуктивності праці і ВВП, як ланцюгової реакції 3 запізненням. Але результативність надто низька. Проблема низької капіталізації в Україні полягає в тому, що кошти використовуються неефективно, а саме не приносять прибутків i дана сфера не розглядається як інвестиційна ніша. I навпаки коли суспільство прагне до саморозвитку, то результативність такого освітнього капіталу підвищується в декілька разів. Йозеф Шумпетер у своїх дослідженнях стверджував, що розвиток відбувається за рахунок впливу лише внутрішніх чинників на економіку, тобто з власної ініціативи [2, c.211].

Сьогодні освіта створює, не лише людський капітал як ключовий фактор розвитку економіки в XXI столітті, саме вона і $є$ зростаючою галуззю економіки. Зростає масштаб ринку освітніх послуг. Експорт освіти, як показує приклад найбільш успішних країн, може становити десятки мільярдів доларів. У США тільки обсяг освітніх кредитів перевищує 1,25 трлн доларів. Інвестиції в людський капітал приносять найбільшу віддачу. Бо людський капітал - це знання, вміння i установки, що дозволяють людині створювати дохід та інші корисні ефекти, що перевершують початкові інвестиції та поточні витрати, для себе, роботодавця i для суспільства в цілому.

Існує пряма залежність між рівнем освіти та рівнем ВВП. Світовий банк, на прикладі обстеження 192 країн, прийшов до висновку, що тільки 16\% економічного зростання в країнах 3 перехідною економікою обумовлені фізичним капіталом, 20\% природним капіталом, а 64\% - людським і соціальним капіталом [9].

Відповідно досягнутий рівень освіти i зростаючий соціальний попит на навчання дають українській економіці цілий ряд переваг. Про що свідчить зростання українського освітнього ринку у вигляді різноманітних освітніх послуг на комерційній основі, незважаючи на те що в Україні гарантовано отримання безкоштовної освіти за більшою частиною основних освітніх програм для школярів та в деякій мірі у вищих навчальних закладах.

Серед них висока активність населення в сфері призначених для користувача інновацій, високе щодо доходу на душу населення культурне споживання i споживання технологічних інновацій. Відповідно до глобального індексу інновацій Україна у 2018 році піднялася на 7 пунктів від попереднього значення і посіла 43 місце серед 126 країн світу. Найвищі 
показники інноваційності Україна демонструє саме в освіті й науці [11].

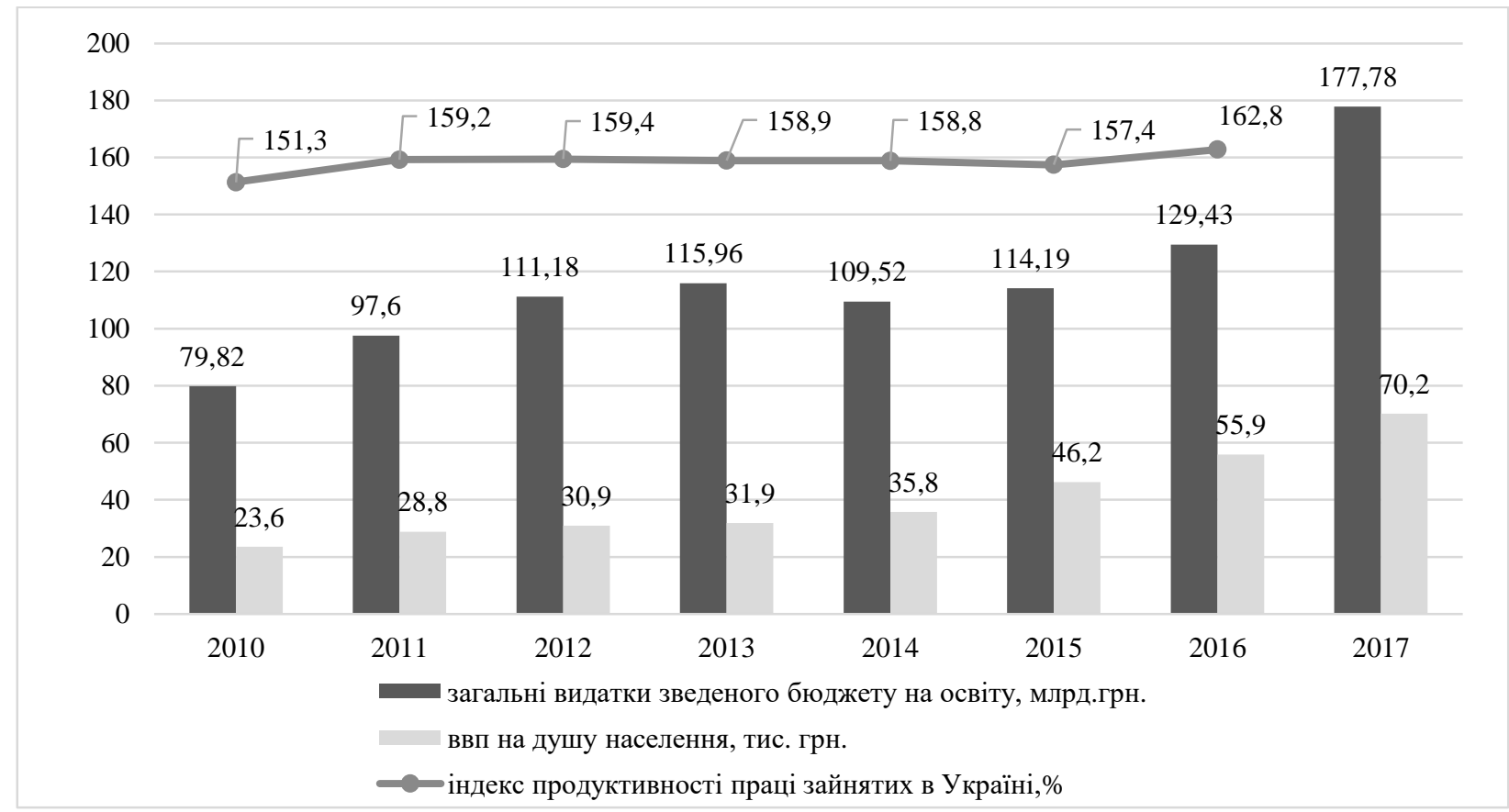

Рис. 3. Динаміка рівня ВВП на душу населення (тис. грн), загальних видатків зведеного бюджету на сферу освіти (млрд. грн.) індексу продуктивності праці в Україні (\%), 2010-2017 рр. Складено автором 3 даними державного комітету статистики

\section{Висновки}

Отже, головною ціллю економічної політики країни має стати перехід до суспільства знань, що вимагає розвитку людського капіталу. Кількісні та якісні зміни людського капіталу в економіці дозволять підвищити як продуктивність праці i споживчий попит, так і підприємницьку активність [6, с. 11]. Відповідно, освіта в сучасній економіці має розглядатися не як витратна сфера поряд iз соціальною допомогою, пенсійною системою, держапаратом, секторів оборони та безпеки, а як інвестиційна сфера, яка визначає масштаб економічного зростання. Бо в умовах глобалізації, економіка знань стає найбільш перспективною моделлю соціального та господарського розвитку, що в своїй основі має зростання ролі науки та освіти для суспільного прогресу. Саме тому, головним стратегічним пріоритетом держави має стати розвиток людського капіталу за рахунок здійснення інвестицій в освіту, науку, професійну підготовку, охорону здоров'я, що забезпечить у майбутньому стабільний макроекономічний ефект та здатність швидко реагувати на глобальні виклики.

\section{Література}

1. Ranieri, Rafael; Ramos, Raquel Almeida (March 2013). (13 January 2015)"Inclusive Growth: Building up a Concept" (PDF). Working Paper. 104. Brazil: International Policy Centre for Inclusive Growth. Retrieved.
2. Schumpeter Josef Alois (1989). Essays on entrepreneurs, innovations, business cycles, and the evolution of capitalism. Ed. by Richard V. Clemence; with a new introduction by Richard Swedberg.-Transactions Publishers.

3. Інновації у вищій освіті: проблеми, досвід, перспективи [Текст]: монографія / за ред. П. Ю. Сауха. - Житомир : Вид-во ЖДУ ім. Івана Франка, 2011. - 444 с.

4. Козенков, Д. С. Інновачійний розвиток та людський потенціал: очінка та стимулювання [Текст] / Д. $С$. Козенков, В. Вашкелєвич, К. М. Солоченко, Е. П. Якубова / Під ред. К. Ф. Ковальчука - Дніпропетровськ : Системні технології, 2004. - $157 \mathrm{c}$.

5. Мельничук, О. П. Освітня складова розвитку трудового потенціалу [Текст] : дис. кан. екон. наук : 08.00.07 / НАН України ; Інститут демографії та соиіальних досліджень ім. М.В. Птухи / О. П. Мельничук - Київ, 2015. - 261 с.

6. Національна доповідь про стан і перспективи розвитку освіти в Украӥні [Електронний ресурс] / за заг. ред. В. Г. Кременя. - Київ : Педагогічна думка, 2016. - 448 с. Режим docmyny:http://lib.iitta.gov.ua/166230/1/nac\%20dopovid\%20 2016.indd\%20smal.pdf

7. Основні показники діяльності вищих навчальних закладів Украйни на початок 2016/17 навчального року. [Електронний pecypc] / Режим доступy: http://www.ukrstat.gov.ua

8. Портер, М. Конкурентная стратегия: Методика анализа отраслей и конкурентов [Текст] / Майкл Е. Портер; Пер. с англ. - М.: Альпина Бизнес Букс, 2005. $454 \mathrm{c}$.

9. Розвиток людського капіталу: на шляху до якісних реформ. [Електронний ресурс] / Центр Розумкова, 2018. 368 c. - Режим доступу:

http://razumkov.org.ua/uploads/article/2018_LUD_KAPITAL.pdf 
10. Стратегія розвитку Європи до 2020 року. [Електронний ресурс] / Режим доступу http://aei.pitt.edu/42633/1/com2010_2020en01_straetry.pdf 11. Global innovation index 2018: Energizing the World with Innovation. Retrieved from:

https://www.globalinnovationindex.org/gii-2018-report

12. Human Development Indices and Indicators: 2018 Statistical update. Retrieved from.

http://www.ua.undp.org/content/ukraine/uk/home/presscenter/ pressreleases/2018/human-development-indices--where-doesukraine-rank--.html

13. Human Capital Project. Retrieved from http://www.worldbank.org/en/publication/human-capital

\section{References}

1. Ranieri, Rafael; Ramos, Raquel Almeida (March 2013). (13 January 2015)"Inclusive Growth: Building up a Concept" (PDF). Working Paper. 104. Brazil: International Policy Centre for Inclusive Growth. Retrieved.

2. Schumpeter Josef Alois (1989). Essays on entrepreneurs, innovations, business cycles, and the evolution of capitalism. Ed. by Richard V. Clemence; with a new introduction by Richard Swedberg.-Transactions Publishers.

3. Sauh, P. (2011). Innovation in Higher Education: Problems, Experience, Perspectives. Zhytomyr, 444.

4. Kovalchuk, K., Kozenkov, D., \& Vashkelevich, V., Soloshenko, K., Yakubova, E. (2004). Innovative development and human potential: assessment and stimulation. System technologies. Dnepropetrovsk, 157.

5. Melnichuk, O. (2015). Educational component of labor potential development. Kyiv, 261.

6. Kremenm, V. (2016). National report on the state and prospects of education in Ukraine. Pedagogical thought. Kyiv, 448. Retrieved from http://lib.iitta.gov.ua/166230/1/nac\%20dopovid\%202016.indd $\% 20$ smal.pdf

7. The main indicators of the activity of higher educational institutions of Ukraine at the beginning of the 2016/17 academic year. Retrieved from http://www.ukrstat.gov.ua

8. Porter, M. (2005). Competitive strategy: An analysis of industries and competitors. Moscow, 454.

9. Human Capital Development: Towards Quality Reforms (2018). Center of Razumkov. 368. Retrieved from http://razumkov.org.ua/uploads/article/2018_LUD_KAPITAL.pdf 10. Europe's development strategy till 2020. Retrieved from http://aei.pitt.edu/42633/1/com2010_2020en01_straetry.pdf

11. Global innovation index 2018: Energizing the World with Innovation. Retrieved from:

https://www.globalinnovationindex.org/gii-2018-report

12. Human Development Indices and Indicators: 2018 Statistical update. Retrieved from.

http://www.ua.undp.org/content/ukraine/uk/home/presscenter/ pressreleases/2018/human-development-indices--where-doesukraine-rank--.html

13. Human Capital Project. Retrieved from http://www.worldbank.org/en/publication/human-capital

Рецензент: д-р економ. наук, доц. Н.М. Богдан, Харківський національний університет міського господарства імені О.М. Бекетова, Харків, Україна
Автор: РИБАК Ганна Іванівна
стариий викладач кафедри економічної теорії та міжнародної економіки
Харківський національний університет міського господарства імені О.М. Бекетова
E-mail-rybakai@ukr.net
ID ORCID: http://orcid.org/0000-0002-4006-4557

\section{EDUCATIONAL POTENTIAL AS THE BASIS OF INNOVATIVE DEVELOPMENT OF UKRAINE: INTERNATIONAL COMPARISON}

H. Rybak

O.M. Beketov National University of Urban Economy in Kharkiv, Ukraine

Educational capital is becoming one of the main factors in the development of economies in the world and society. Investing in human capital stimulates the pace of economic growth, which is a prerequisite for the competitiveness of the country on the world stage. The quality of human capital is a greater extent shaped by the education system.

For the Ukrainian economy, with its imperfect institutions, this element of human capital is of fundamental importance, since it contains reserves for institutional renewal not only of the business environment, but also of social institutions. In recent years, the key element of human capital of the country has become intellectual capital - the ability to generate and develop innovation, a kind of economic projection of creative activity. Intellectual capital is crucial for the modernization of the economy, the transition to new technological developments. The most important characteristics of educational potential are the population coverage of different types and forms of general and vocational education, its qualitative parameters, the state of infrastructure, financial component and development after university education, the level of population culture and its outlook orientation, spiritual development, the ability to systematically receive and use the necessary information.

Education in the modern economy should be considered not as a spending field, along with social assistance, pension system, state apparatus, defense and security sectors, but as an investment sphere that determines the scale of economic growth.

The main strategic priority of the state should be the development of human capital through investments in education, science, training, health care, which will ensure in the future a stable macroeconomic effect and the ability to respond quickly to global challenges.

Keywords: innovative development, educational capital, educational potential, inclusive development, institutionalization of innovation development, capitalization of educational capital. 